\title{
Male Friendship As Masculine Individuation in Romeo and Juliet
}

\author{
Halide Aral, M.A. \\ University of Çankaya
}

\begin{abstract}
The purpose of this essay is to analyse from a Jungian perspective how heroic masculinity and Christianity, due to their negative attitude toward the feminine, problematize masculine individuation and cause tragedy in Romeo and Juliet. Although all male characters in Verona fall short of the mature masculinity that could come with developing a relation to the feminine, I focus on Romeo and Mercutio whose problematic development clarifies man's difficulty with integrating the feminine without forgoing the masculine structure. Romeo, the puer, who represents the spirit, suffers from a positive mother complex. Mercutio, the trickster, the dark side of the puer, represents the body which is considered evil by Christianity, and has a disturbed relation to the feminine. Hence he compensates for, completes, and gives body to Romeo who is otherwise nothing but the spirit. Being the evil component, Mercutio is essential to the individuation process, and with his simultaneous resistance to and what seems to be an unconscious identification with the feminine, Mercutio serves as a medium through which Shakespeare presents what we may now call, following Eugene Monick's model, bisexual androgyny as an alternative to heroic masculinity. But this potential as embodied in Mercutio is wasted tragically by the heroic masculinity in Verona.
\end{abstract}

Shakespeare in Romeo and Juliet presents to us the friendship of two young men, Romeo and Mercutio, who are in the process of growing into manhood and recognize that their friendship conflicts with heterosexual love. While Romeo commits himself to love, Mercutio rejects it and commits himself to male camaraderie. With their different attitudes to love and the opposite sex, Romeo and Mercutio represent the adolescent or in Jungian terms the puer stage of masculine initiation in a patriarchal order that undercuts the development of mature masculinity by encouraging heroic masculinity and eliminating the feminine. While Romeo is portrayed in the process of trying to grow past the puer stage and relate to the feminine, Mercutio is represented as the trickster, the shadow of the puer, namely, all immature and self-destructive attitudes. Hence he displays a problematic development. The development of these two young men is overshadowed by the Christ image as pure spirit. Mercutio refuses heterosexual love and resists the anima, his feminine side. But the fear of the anima is accompanied by what seems to be anima identification, which he is unwilling to admit and address. This complex state opens up for such a mercurial character, as an alternative to patriarchal masculinity, the possibility of bisexual androgyny as proposed by Eugene Monick (Phallos 70). It also can be read as proto-heterosexuality, which is implicit in some of his bawdy jokes.

The friendship of Romeo and Mercutio is based on a compensatory structure. They are in a sense the opposites of spirit and matter as the dichotomy of good (spirit) and evil (body) as conceived in Christianity. Romeo, the Petrarchan lover, whose experience of love is entirely spiritual and narcissistic, is pure spirit and ignores the body. His love for Rosaline is spiritual, and he continues with the same attitude, as the pilgrim image and the religious language in his first encounter with Juliet implies, until Juliet draws him to the body. Romeo's spirituality is linked with Christian culture's idealizing notions of the human potential for redemption. The purity of Christ as anima rationalis serves to deny the body, which is regarded as the rejected shadow of the Christian culture and makes individuation problematic since individuation requires acknowledgement of and ethically coping with one's own evil. The Renaissance was a time when Medieval spirituality began to confront corporeality and the body was valued as well as the spirit. It was therefore also a time, as Jung points out, when the historical process leading to the Antichrist began, and "The ideal of 
spirituality striving for the heights was doomed to clash with the materialistic earth-bound passion to conquer matter and master the world” (CW 9ii, par. 78, 43). It is in this sense that Mercutio becomes crucial in understanding Shakespeare's preoccupation with initiation as a Renaissance man. Mercutio, with his corporeality and pagan attitude, as Clifford Leech (21) points out, represents this attitude. He brings the body, the problem of evil, into play and summons Romeo to an awareness of human reality not just as spirit but as matter, too: "I conjure only but to raise up him" (2.1.29). By leaving the shadow, the physical desire, out from the start and devoting himself to emotion only, Romeo ensures the tragedy: the feminine, the body, and even necessary evil all die with Romeo and Juliet. Therefore, a dark, near-evil side to Mercutio, which like the spirit Mercurius that rules over the dark but mutative art of alchemy, is essential for the transformation of the body that is part not only of adolescence but also of psychological individuation into a more mature integrity. So the shadow needs to be integrated both by Romeo and Mercutio. The shadow problem is what Shakespeare portrays as the crux in their relationship, and he works on it without knowing yet the solution.

The conflicting demands of heterosexual love and male friendship have been surveyed by present-day commentators who have agreed that Romeo needs to grow past Mercutio to form his masculine selfhood in heterosexual union. Feminist-psychoanalytic critics like Coppélia Kahn (Coming of Age), Janet Adelman (Male Bonding), and others pay much attention to this conflict as well as masculine identity, and Romeo is regarded as moving from adolescence to maturity through marriage. Marjorie B. Garber, for instance, sees Romeo's leaping over the orchard wall as a symbol of his initiation or what she calls "literal threshold” (Coming of Age 9). In fact, by doing so Romeo becomes able to relate to the feminine, i.e., to grow up and be fruitful, like the trees in the garden. Mercutio, on the other hand, is thought to be stuck in adolescence with his "ithyphallic" masculinity, his fear of emotions, "of real love that would lay him down," as Norman N. Holland argues (11). His scorn for heterosexual love, his misogyny, and his loyalty to male camaraderie might also be regarded as signs of homosexuality. Joseph. A. Porter, who refers to "a fleeting suggestion of” sodomy in Mercutio’s speech (Shakespeare’s Mercutio 236), holds that "Mercutio . . . points like a roadside herm to a fraternally bonded realm, with its attendant latent misogyny, and homosexuality and with its gratifications including strong friendship and celebration of the phallus” (157-58).

\section{Mercutio as a Model of Bisexual Androgyny}

In Mercutio’s person and through his friendship with Romeo within an overwhelmingly phallic and violent context, Shakespeare focuses on a difficult phase of masculine initiation, beyond the too-soulful puer aeternus that it is Romeo's tragedy to remain forever in our hearts, since he dies young and for love, becoming literature's chief image of the eternal adolescent lover. The ruthless shadow he would have had to integrate to get beyond this all-too-faithful service to youthful eros is a stage in the initiation process into adult manhood that has been emphasized by the Jungian analyst Joseph L. Henderson in his book Thresholds of Initiation. The trickster in Jungian psychology is Mercurius, who presided over the transformations beyond original chemical boundaries that made Renaissance alchemy possible and who still appears in the dreams of modern analysands. This mythologem was well known in Shakespeare's time, and Mercutio's connection with his namesake Mercury has been dealt with by Porter in his groundbreaking study of the character. The links with the trickster mythologem have been pointed out by Thomas Browne who considers Mercutio as the shadow or the dark side of Romeo. He points out the trickster's fear of the feminine, his irresponsibility, and his primitive nature with reference to Jung's essay on the trickster. He regards Mercutio as an adolescent who possibly has no sexual experience and lacks sexual prowess, is unsure of himself, and always shows "whenever he appears on stage a remarkable lack of empathy for Romeo" because he is afraid of his own femininity(47). He lives "on the edge" (48), is always aggressive, seeks death, and fights Tybalt “to test his weapon against Tybalt's new toy” (48). I find Browne’s account of Mercutio quite remarkable in 
that he gives a list of all his negative traits, has no sympathy for why they should be necessary in the process of maturation, and dismisses the positive aspects of the character.

He might, however, have noted something Jung wrote in Aion about a young man's need to integrate just these negative traits to be able to grow beyond the mother-fixation by becoming independent of her in order to avoid repeating his excessive loyalty to love in immature ways in his first relations with women. The young man, in Jung's view, is attached to his mother who is his first love and wants to be faithful to her, and sometimes the mother encourages such loyalty to keep him in her domain instead of letting him go out into the real world of risks to become a man. So as Jung wisely sees, the loyalty to the mother keeps the son from actively and judiciously enacting his "desire to touch reality, to embrace the earth and fructify the field of the world. , , For this [independence] he would need a faithless Eros, one capable of forgetting his mother and undergoing the pain of relinquishing the first love of his life.” (CW 9ii, par. 22, 12). The faithless eros Romeo would need to resove the love problem, constellated by his desire to build a life with Juliet for which his present level of emotional development is simply not adequate, is personified by Mercutio. Compared to Mercutio, Romeo is even more immature since Romeo now transfers all his eros to Juliet. Shakepeare seems to be more impartial and thoughtful about the implications of Mercutio's trickster qualities, especially his detachment from the feminine as the sign of desire to maintain masculinity.

As I have argued, Mercutio represents the trickster stage of masculine development, and the trickster, as Jung says and Browne also points out (47), fears his own feminine, the anima. In Henderson's formulation, trickster figures suffer from a mother complex (24) and are boyish in their relations with women (31) or resort to male camaraderie where they feel safe. Mercutio, the trickster, scorns heterosexual love: "for this drivelling love is like a great natural that runs lolling up and down to hide his bauble in a hole" (2.4.91-93). In addition his misogyny colors his descriptions of Rosaline as a tormentor, and of maids as dreaming of sex only to become "women of good carriage. . . ." It seems Mercutio would feel safe in his single truckle bed rather than in the bed of a woman: "I'll to my truckle-bed. / This field-bed is too cold for me to sleep" (2.1.39-40) while Romeo does just the opposite. We cannot, however, be sure whether Mercutio's dislike of romantic love and women is caused by an external feminine figure or his inner feminine. The feminine figures in the play-Rosaline, the Nurse, Lady Capulet (who plans to get Romeo killed in Mantua), Lady Montague, and even Queen Mab herself—are all negative feminine figures in that they are more like stereotypes who represent the role attributed to women by the patriarchal world of Verona than characters who could evoke a sense of individuality, as Juliet does. The feminine figures' failure to be individuals enables Mercutio to generalize about women and disdain them as he does Rosaline, the Nurse, and the Mab herself as troublemakers. But his fear of the feminine and the negative feminine figures distorts his vision, and he is not open to an exceptional, positive anima figure like Juliet who has a sense of autonomy and integrity.

The predominance of the shadow definitely makes Mercutio a difficult figure. He has "the daemonic" (18) as Leech argues. Further as observed by Browne (44) he finds himself ugly, like the mask with "beetle brows" that will hide his own deformities too: “A visor for a visor . . . / What curious eye doth quote deformities?” (1.4.30-31). Surely it is the shameless trickster who is speaking here. But we need to ask if he is really not worried about his negative self-image. The fact that he sees his face as a mask is indeed alarming in many ways. Frank Occhiogrosso asks if Mercutio is "a pretender whose outer life covers an inner one that he consciously seeks to hide” (5). In his view the broken syntax peculiar to Mercutio's speech indicates a mental instability (6) and his caricature of Benvolio, being a projection of his own character, reveals a paranoid schizophrenic mind (12).

In his analysis of the character in his introduction to the Arden edition of the play, Brian Gibbons attributes mania to Mercutio's description of Tybalt (68). Mercutio, I think, might fit better in general in manic disorder with some of his trickster characteristics: unpredictability, sociopathy, disruptiveness, and destructiveness. His Mercurial gift of language in the Mab speech also reveals the pressure of speech peculiar to 
mania. He speaks with urgency, his thoughts race with abundance, and he is frustrated (for not being understood or taken seriously perhaps) when asked to calm down. Nevertheless, his disorder does not reduce the truth of his vision of dreams. They are in the Freudian sense a reflection of hidden desires, or wish-fullfilment and selfdeception, though they might as well be prophetic, as Romeo suspects.

Despite his manic tendency, Mercutio seems not to project his irascibility onto Benvolio. His remark about Benvolio's quarrelsomeness:” Thou wilt quarrel with a man for cracking nuts, having no other reason but because thou hast hazel eyes” (3.1.18-20) is ironic and aimed to tease. His reference to Romeo as a madman is not a projection either since a lover's melancholy was considered akin to madness in the 16th century. Indeed, Romeo himself too calls love "A madness most discreet” (1.1.191) and replies to Benvolio: "Not mad, but bound more than a madman is" (1.2.54). Mercutio's idiosyncratic broken-syntax-for example, his description of Romeo: "Stabbed with a white wench’s black eye, run through the ear with a love song" (2.4.13-15; or of Tybalt: "the very butcher of a silk button-a duellist, ... Ah, the immortal passado, the punto reverso, the hay!"(2.4.23-26) — has much to do with the way Shakespeare paints an intelligent, poetic, and philosophical mind, not a formless one, as Occhiogrosso argues (6). It seems as if Mercutio has the full text in his mind, but he keeps it to himself in the company of his friends who fall short of coming up to his standards of perceptiveness. Are Benvolio and Romeo capable of social criticism and a philosophical outlook on life? Would they ever understand why the upstart, opportunistic, nouveau riche Tybalt upsets Mercutio? So why would Mercutio talk in detailed full syntax? Mercutio is solitary in the company of his decent but shallow friends. If not in terms of masculine development, he surely is more mature or precocious than they are in terms of his complex vision of life and insight into people.

Mercutio's restlessness raises the question of masculine integrity, and his urgent need for integrity becomes clear in that infamous Queen Mab speech which reveals his contradictions. On the surface this highly imaginative speech contradicts the realistic and materialistic Mercutio who thinks that dreams are the product of the trickster-like Mab who knows our desires and plays with them. But when viewed in light of Jung's perspective on masculine initiation, the contradiction becomes more understandable. After all, Mercutio is "an evasive trickster” like the Mercurius who "consists of all conceivable opposites” (Jung, Aspects 160). The Mab speech is not a deliberate act but a spontaneous attack that catches Mercutio unawares. It is essential to the plot in that it pinpoints Mercutio's problem with the feminine and even makes it prominent. The speech signifies a sudden upsurge of the anima because it displays a highly developed feminine sensibility in its generative imaginative power, the delicacy and fragility of its imagery, and its attention to minute detail. The language surely reveals the sensibility that Mercutio has hidden from himself:

Her chariot is an empty hazelnut

Her wagon-spokes made of long spinners' legs,

The cover of the wings of grasshoppers,

Her traces of the smallest spider web

Her collars of the moonshine's watery beams, Her whip of cricket's bone, the lash of film,

Her waggoner a small grey-coated gnat. (1.4.59-67)

Mercutio's fine poetic perception here underlines how sensitive and vulnerable he is, and the speech involves no bawdiness - to Browne's surprise-because it is the suppressed or denied feminine who, freed from the disguise of sex-role, is speaking here with full gravity, demanding attention with an implicit threat of what might happen if she is not heeded. That is, the feminine in Mercutio makes a demand for recognition, for integration into himself, and threatens him with the power of imagination, which certainly has the potential to induce madness. This threat is what Benvolio senses in Mercutio's remark on the wind, and he responds with fear: "This wind you talk of blows us from ourselves" (1.4.104). Despite his machismo 
and phallicism this feminine sensibility suggests that Mercutio might well have identified with the anima, and his strong hold on phallicism and bawdiness might be resistance to the overpowering feminine and overcompensation for the absence of a strong inner masculine structure.

Mercutio's response to Romeo's lines_-“True, I talk of dreams, / Which are the children of an idle brain" (1.4.97-98)—sounds rueful, and this tone is significant in that it emphasizes the lack of true empathy on Romeo's part. Instead of trying to understand his friend and take him seriously, Romeo abruptly interrupts him in an offensive way: “Thou talk'st of nothing” (1.4.96). We come to see very keenly at the end of this manic speech Mercutio's philosophical distance from ordinary human life. It reveals the aristocratic Mercutio's alienation in Verona's hostile and prosaic world. Most movingly, it shows his desperate need for Romeo's love and support. It is as if Mercutio is lost and angry about his rejection like the wind he describes:

who woos

Even now the frozen bosom of the north

And, being anger'd, puffs away from thence

Turning his side to the dew-dropping south. (1.4.100-03)

The fineness of poetry he speaks in this scene clarifies Mercutio's suppression of his feminine side, his soul, which could connect him to himself and which could make him a romantic lover, one perhaps even more refined and gracious than Romeo, as his romantic sensibility suggests. The emotional, romantic, spiritual Romeo is, in effect, the externalization of what Mercutio denies in himself. This projection is one of the reasons why Mercutio is so strongly attracted to him.

But the suppression of the inner feminine causes both rage and aggression in Mercutio. His aggressiveness, however, is different from Tybalt's. Tybalt is aggressive because he conforms to the code of masculinity in patriarchal and violent Verona, as his promptness to fight in the first scene of the play implies. His sort of aggression is what Eugene Monick calls "pseudo phallos . . . a faulted effort to express manliness" (104). He has a reputation for being fiery and promptly responds with violence when he hears Romeo at the ball: “This by his voice should be a Montegue / Fetch me my rapier, boy” (1.5.53-54). Then he insists on the family honor and seeks revenge. Mercutio's aggressiveness is more like a phallic woundpossibly caused by the mother-indicating the lack of a secure and stable masculine structure. One of the reasons why he hates Tybalt is that his phallic wound is provoked by Tybalt's air of masculine superiority as he shows in his naming of Tybalt "the rat-catcher" and "Prince of Cats." Thus he speaks with nonchalance and deliberately agitates Tybalt: "And but one word with one of us? Couple it with something, make it a word and a blow” (3.1.39-40) and “Could you not take some occasion without giving?” (3.1.43).

In terms of masculine development in patriarchy, Tybalt and Mercutio are essentially the opposites: the former represents the adversary of the puer, the senex, which means, as James Hillman describes, time, order, structure, precision, and at the same time death when it disconnects from the renewing spirit of the puer: "Senex consciousness when split from the puer offers this chronic invitation to destruction" (278). The name "The Prince of Cats" with the association of wisdom or caution and "the courageous captain of compliments" capable of cutting a silk button denotes senex qualities such as calculation, precision and timing. Tybalt himself confirms these traits in the ball scene: "I will withdraw; but this intrusion shall / Now seeming sweet, convert to bitt'rest gall” (1.5.90-91). Moreover, he never appears as a jovial young man. He is always sober, warrior-like and aims to kill without hesitation: "Turn thee, Benvolio, look upon thy death" (1.1.64). In the play's world Tybalt is a father's son and thus outside the mother complex altogether. As Kirby Farrell aptly observes, he is the "surrogate son" who "boldly usurps the role of the warrior lord (Capulet)" (91) and "refuses to take his proper place in the hierarchy of male authority” as Dympna C. Callaghan notices (96). Tybalt is in this sense the negative to both Romeo and 
Mercutio who represent positive and negative attitudes toward the mother as puer and trickster, respectively. In other words, we do not witness in Tybalt any unease with his masculine role, nor does he display a personality having trouble with the feminine in the form of resistance or engulfment. He just disregards it to adjust to his role as a man. In this respect he shows the negative side of patriarchal masculinity, which eliminates the feminine altogether.

If we accept this unconscious anima identification and the accompanying shadow problem, we must see the vivid Mercutio carrying the individuation energy that the "star-cross'd" (1. Prologue. 6) lovers destined to die in adolescence could not carry forward in a mature manner. The individuation energy is what endows Mercutio with a unique status: being inspired by Mercury and the trickster, Mercutio bears the basically male but androgynous character of this god and yet like the trickster "disturbs the webs of signification" (Hyde 74) and refuses to choose between one of the opposites, pointing to a third option. That third option as explored in Mercutio is, I believe, bisexual androgyny as proposed by Monick rather than heterosexuality or homosexuality. Monick regards Jung's concept of the pyschoid unconscious as foundational because it contains the masculine and the feminine in parity. That is, the deepest source of instinct, which transforms penis into phallus, is not maternal only: it is also paternal and hence has transgressivity. The presence of the feminine and the masculine in parity in the unconscious "offers a man a way to return to the unconscious without surrendering his phallic identity" when he individuates (62). The psychoid unconscious, Monick believes, also erases the power struggle between matriarchy and patriarchy. It does not require the diminishing of the feminine to establish the masculine but opens the path to New Consciousness, which includes androgyny as the solution to the power struggle between sexes:

The androgyne knows the difference between masculinity and femininity, and chooses to incorporate an owned portion of the opposite gender into his or her dominant identity. An androgynous person does not pretend to be a member of the opposite sex. An androgynous male will not repress his feminine characteristics, however much he may, at times, decide to suppress them. He knows that they are a part of him, he has worked on his ego resistance to integrating them. (70-71)

Mercurius, the phallic god, the masculine spirit, carries the characteristics of psychoid phallus, according to Monick, because even though he is male, he is also dualistic as male and female. How does Monick's idea of the psychoid unconscious relate to Mercutio? It does in a Mercurial and contradictory way. Mercutio, with his Mercurial dualistic stance, seems to carry the seeds of a new understanding of masculinity that many men still reject or cannot internalize today. In other words, he turns our attention to a definition of manhood beyond patriarchy, one that affirms and integrates the feminine without foregoing the masculine structure. To clarify this point further we need to see Mercutio in his social context.

Mercutio does not fall into the patriarchal definition of man despite his phallicism aggressiveness, and misogyny. All the male characters in the play except Mercutio are well adapted to their sex-roles and are at peace with themselves. Romeo experiences the feminine through his love for Juliet while the other male characters seem to have repressed the feminine. In the play's patriarchal world they all display the kind of masculinity that aims at the hero as the ultimate model that Robert Moore and Douglas Gilette call "boy psychology" (xvi). Tybalt, for instance, is the epitome of this masculinity in its shadow form, namely, the grandstander bully. Mercutio, however, with his powerful suppressed anima, his refusal to be a husband, and his in-between masculine stance does not fit the male stereotype. His problematic relationship with the anima pushes him away from one-sided masculinity, and his distance from the male stereotype renders Mercutio the kind of man who is capable of androgyny. Therefore it seems "God hath made, [him] himself to mar" (2.4.114-15). Mercutio mars his friend as well as God and us. His bawdy jokes, which have implications of sodomy, whether it be homosexual or heterosexual are more related to the lower masculinity that needs to penetrate the mature masculinity. Mercutio, however, by denying the anima denies himself a more mature masculinity. Interestingly his motherboundness 
makes him a victim if not the scapegoat of patriarchy. In a patriarchal order he seems to be lacking a father figure to relate to.

Mercutio's detachment from the hero is further clarified in his identification with the warrior. He has none of the hero's tendency to dramatize his actions, sense of potency and invulnerability (Moore and Gilette 80-83). Mercutio as a warrior can commit himself to a transpersonal cause, and this, too, contradicts the Mercutio who is imaginative and feminine in the Mab speech. He fights for the cause of friendship with his loyalty to the feudal code of honor. His knowledge of fencing and his detailed depiction of the soldier in the Mab speech are related to his warrior character. Although he lacks the precision of the warrior that Tybalt embodies, Mercutio is aware of his own limitations before his opponent and fights with discernment and ethics. Tybalt's passion suits the shadow warrior. He is cruel and does not aim to destroy only what needs to be destroyed. He fights for a personal cause. Moore and Gilette argue that the shadow warrior "carries into adulthood the adolescent insecurity, violent emotionalism, and the desperation of the hero as he seeks to make a stand against the overwhelming power of the feminine” (90). Mercutio, however, has positive warrior energy. He is not motivated by hatred or cruelty and wants to destroy what should be destroyed, namely, Tybalt, who with unrelenting and incurable hatred insists on bloodfeud and says: "and talk of peace? I hate the word" (1.1.67).

Mercutio's strict adherence to the warrior and failure to ally with the lover archetype, however, has unfortunate consequences. Not connecting with the lover archetype prevents warriors from relating to human beings and to women, say Moore and Gilette (88). Despite his joviality and sociable attitude Mercutio cannot relate to people, as his ironic teasing of Benvolio shows: "Why, thou wilt quarrel with a man that hath a hair more or a hair less in his beard than thou hast” (3.1.16-18). Benvolio, the peacemaker, is not the man Mercutio describes - we have seen him trying to calm down the servants right in the opening scene. The title of quarrelsome man suits Mercutio better. Benvolio indeed confirms Mercutio's irascibility: "And I were so apt to quarrel as thou art, any man should buy the simple fee of my life for an hour and a quarter" (3.1.31-33). Soon we witness the truth of what Benvolio says when Mercutio attacks Tybalt both verbally and physically.

Being cut off from the lover creates another crucial problem for Mercutio because it disables his vertical creativity and hence poses the danger of spiritual castration for him. The trickster/puer Mercutio is basically vertical, and verticality, as Hillman defines it, is "the break in and break with the horizontal [realistic] outlook of the daily life" (159). It is the creative spirit that endows the puer ego with the ambition to ascend, transcend the institutionalized father, and aspire to "redemption, beauty, love, joy, justice, honour" (175). Despite his realist stance Mercutio has a poet's soul. Verona does not satisfy his aesthetic aspirations, which he pushes down, and he does not know what to do with that artistic energy that could nourish his soul and help him heal his chaos. So he defensively confines himself to a realistic perception because he cannot reconcile the contradictory demands of the anima and the patriarchal manhood or the lover and the warrior. His being trapped in a state of contradictions disrupts the development of verticality, and Mercutio then becomes the man he is-restless, aggressive, and demonic.

His vertical drive also distances him from women because puer sexuality is penis-focused (Hillman 167) and because his resistance to the mother enables him to belittle women. At the end of the Mab speech, the image of maids suggests that he grudgingly accepts their role in being the origin of man. Mercutio mocks the Nurse, and his bitterness toward her imagined sex-role does not exactly suit the warrior's attitude toward woman as a source of a pleasurable release. His negative attitude to women or sexual experience is related to the puer problem as Hilman explains: "But within the vertical cosmos of the puer, erection does not make babies, it makes love. And the love it makes is not necessarily related, but fun, inspiring, revelatory, impersonal, imaginative” (168). Mercutio shows little erotic interest in women and, as 
Romeo tells us, speaks more about sex than performs it: "[he] will speak more in a minute than he will stand to in a month" (2.4.145-46). Mercutio's detachment from sexuality suggests that he is not interested in sex for its own sake. It seems more likely that he disdains women for the role they are made to play in patriarchal marriage and keeps away from any involvement with women as implied in his description of Mab' mischiefs: "when maids lie on their backs, / That presses them and learns them first to bear" (1.4.92-93). The Nurse in fact voices this idea—reporting her husband's remark about Juliet—earlier than Mercutio does: "Thou wilt fall backward when thou comest to age" (1.3.56). What women are made to see as their only function, that is, to learn to bear weight whether it be that of a man or a child, Mercutio sees as abominable. Yet Mercutio's distance from women and sex also indicates the puer's desire to be "free of the horizontal trap and being yoked to vegetative service" (Hillman 170) the puer's unwillingness, to bear the responsibility of a child as well. Also his disdain for the Nurse is consistent with his deep psychological role in the play, which is to refuse all eros connected with the mother. Romeo, having transferred the entirety of his mother complex onto his relationship with Juliet, cannot achieve any distance from eros. Romeo's love for Juliet has foreseeably tragic results because he devotes himself to Juliet, marries her without considering the consequences, and paves the way to the tragedy for all.

\section{Romeo as the Archetype of the Lover}

Mercutio's disconnectedness from the lover archetype makes Romeo all the more indispensible to him. Romeo fits the lover archetype, which Mercutio at once suppresses and desperately needs. The lover is sensitive, sensual, spiritual, able to enjoy life and cope with its hardships (Moore and Gilette 120-124). But when we first meet him in love with Rosaline, Romeo is more like the shadow of the lover archetype. He is self-indulgent, lost in sensations, chaotic, and off-center: "I have lost myself” (1.1.195). But when he falls in love with Juliet, Romeo moves into the positive side of the lover and is now centered: "Turn back, dull earth and find thy centre out” (2.1.2). Being centered reinforces his relation to the feminine and Romeo's physical encounter with the feminine begins in the ball scene with the touching of palms (a symbol of the feminine). “And palm to palm is holy palmers' kiss” (1.5.99). So to appreciate Romeo as a positive lover we need to recall further the characteristics of the lover archetype.

The lover lives in his body without shame, is sensual and compassionate. He connects to the world through feeling rather than intellect, so he is close to the unconscious. He wants to touch and to be touched physically and emotionally. He has aesthetic consciousness and is the source of spirituality. He is the archetype of the joy of life and endures the pain of love and other people. He crosses social boundaries, so his life is unconventional like that of an artist. Romeo bears almost all of these characteristics (Moore and Gilette 121-126). He is sensitive to beauty: "It seems she hangs upon the cheek of night / As a rich jewel in an Ethiop's ear" (1.5.44-45). He touches Juliet and wants to be touched by her both physically and emotionally: "O that I were a glove upon that hand, / That I might touch that cheek" (2.2.23-24). Unlike Mercutio, he is not worried about his physical appearance, so he is not ashamed of being in his body (the promptness with which he kisses Juliet). He trespasses across the social boundaries (the family feud, by marrying Juliet). He bears the pain of love and comes to endure the misery of life in Mantua and has sympathy for others' pain (he feels for the apothecary's misery). He is spiritual because love for him is a sacred act: "I'll watch her place of stand, / And touching hers, make blessed my rude hand" (1.5.49-50). He is intuitive and close to the unconscious as his prophetic dreams indicate. Being so emotional and close to the unconscious, however, definitely brings him close to destruction within a context that condemns feelings, sensitivity and love. Romeo comes to see the truth about the mercantile and patriarchal Verona only too late: "There is thy gold-worse poison to men's souls, / Doing more murder in this loathsome world" (5.1.80-81). 
Romeo's ability to experience his feelings freely, even though his feelings are artificial in the beginning, is exactly what Mercutio lacks, and this creates a tension between them. In fact, when we meet them first their friendship is already under stress. Romeo does not receive, or so he thinks, the due empathy from his friend and is resentful: "Thou wast never with me for anything, when thou wast not there for the goose” (2.4.76-77). This response is too harsh and not true because we know from both Benvolio and Mercutio that Romeo's whining about Rosaline is irksome and does not deserve much attention. Not knowing that "He is a bit of a bore and a pest to his friends," as Allan Bloom rightly says (109), Romeo even goes further to insult Mercutio: "God hath made, himself to mar" (2.4.114-15), "that loves to hear himself talk, and will speak more in a minute than he will stand to in a month" (2.4.144-46). "He jests at scars that never felt a wound" (2.2.1). Despite his lack of empathy Mercuto is never this personal and offensive to his friend. He mocks in order to cure, not to offend Romeo and is affectionate and tolerant even when he is hurt: "I will bite thee by the ear for that jest" (2.4.78). Although as Alan Sinfield holds, "He is trying a bit too hard, all the way through, to get Romeo's attention” (92), Mercutio is seriously concerned for his friend's well-being. He fears that Romeo will run mad because of Rosaline. He fights and dies primarily for Romeo's honor and no doubt for his own because he regards his friend's honor and his own as the same. Such is Mercutio's notion of friendship. Romeo, however, falls short of such a mature code. Also he makes a serious mistake by intervening in the duel between Mercutio and Tybalt and unwittingly causes his friend's death.

Romeo is so peaceful and love-oriented that he cannot understand hatred and hostility. He is like an alien in Verona. So he is ridiculously naive and fails to grasp how dangerous Tybalt is. His response to Mercutio’s blaming him, "I thought all for the best” (3.1.106), therefore, sounds "feeble" and "shocking in its obtuseness" as Nicholas Brooke says (83). Romeo is not just emotionally immature; he is immature in his knowledge of the ways of the world: he has failed to learn by the end of the play since he still calls Tybalt "cousin" in the grave before he dies. What matters, however, is the change in Romeo before Tybalt returns. He abides by the patriarchal definition of manhood by regarding his peacefulness as emasculation and fighting Tybalt only after Mercutio is wounded: "O sweet Juliet, / Thy beauty hath made me effeminate" (3.1.115-16).

Romeo's conforming to violent masculinity is surely crucial in terms of Shakespeare's insight into the difficulty patriarchy poses for Romeo in its very "nervousness about male effeminacy and women out of place” (Sinfield 98). He is not given a chance to grow up because of the definition of so-called mature manhood. That is, by being violent he blocks his own path to life and growth. But even if Romeo were given the chance, the hero stage would be as far as he could go, and that would have led to the solar masculinity that would again mean elimination of the physical and the feminine at some point. Since patriarchy aims to eliminate the feminine in all stages of masculine development, the code of masculinity in Verona would not allow the true individuation for man that comes with a return to the anima, the feminine that Jung emphasizes as essential to true male individuation. The father figures, Capulet and Montague, are men who cannot go beyond heroic masculinity since they perpetuate the hero attitude and the feud. Hence they are also caught in the patriarchal trap. Mercutio, unlike Romeo, who is about to move into the hero stage falls outside this norm. He cannot or even may not wish to cross over to the hero stage because his struggle with the feminine binds him to adolescence. Hence the definition of patriarchy as boy psychology by Moore and Gilette makes so much sense when Romeo's process of growing up is looked at closely.

His love for Juliet transforms Romeo. But we have to ask if the veneration some critics have for the character is based on the attachment we all have to the adolescent idealism of our first approaches to love, to which some remain unconsciously attached for a lifetime. To be sure, there is a certain integrity in Romeo's remaining true to his eros, but we should not forget how foolish this also is, for in fact he is unable to bring that love to mature expression, as a lived marriage against the odds might have done. 
Narcissistically centered in his love and his grief when he imagines he has lost his love, Romeo has a long way to go to become a mature man, to activate the lover's capacity to deal with the hardships of life. But the emotional Romeo is in fact fatalistic, as some commentators of the play notice, and it is not a surprise that Shakespeare makes Romeo's dreams prophetic in the way of men perhaps too close to the unconscious. We have to recognize how passive his relation to the deep Self is because Romeo does not reflect on his dreams and follow the warnings that come from that hidden world. On several occasions he voices his submission to the stars as the superior governing principle, as if their decrees are unalterable. Hyde clarifies the relation of design and choice: "There are designs in this world, but there are also chance events, which means the design is never finished . . . human beings have a way to enter into the play of fate" (127). Unfortunately Romeo does not know what it means to make a choice and hold the tiller. He leaves all his choices to the unconscious instead of reflecting on the pros and cons of the action. Although he fears an early death that the dream explicitly warns about, he does not follow his intuitions and avoid the course of action that could turn his terrible dream into reality. He leaves it all to fate and goes to the ball: "But he that hath the steerage of my course / Direct my suit" (1.4.112-13). After the news of Mercutio's death his logic is deterministic: "This day's black fate on mo days doth depend" (3.1.121). He kills Tybalt and thinks that he is "fortune's fool." Then he interprets his dream in Mantua positively because with death hovering over him he desperately needs some hope to survive:

If I may trust the flattering truth of sleep

My dreams presage some joyful news at hand.

My bosom's lord sits lightly in his throne;

And all this day an unaccustom'd spirit

Lifts me above the ground with cheerful thoughts.

I dreamt my lady came and found me dead-

$\ldots$

And breath'd such life with kisses in my lips

That I reviv'd and was an emperor. (5.1.1-9)

Garber (Dream) rightly reads this dream on both literal and metaphorical levels. She says that Romeo's death and Juliet's kissing him turn out to be literally true but that his being revived by Juliet's kiss is to be taken metaphorically. Garber thinks that he will be enshrined only after death when his statue in gold is raised by the Capulets (45). Yet there is more to this very symbolic and complex dream and the metaphor of emperor, which Romeo unfortunately misinterprets. Being found dead by Juliet does not worry him; he focuses on the deceptively better side of it, namely, being resurrected and becoming an emperor. The dream, like the first one, is an example of synchronicity. But Romeo cannot read the subtlety of the image of becoming an emperor after death. He cannot help being rash and heads to his destruction. The image of an emperor is highly significant in that it is linked with the archetype of the king, the primal energy that brings order out of chaos, and points to Romeo's desire to become a mature man, one who can relate to the anima. The dream also reveals the tragic fact that in his character masculinity beyond the hero is not possible; it can be realized even as a potential only after death.

The archetype of the king in positive terms is important because the fathers in Verona are far from being the examplars of this archetype. Moore and Gilette say that the king archetype is larger than the father. It follows the hero's death and is the center of man's psyche. The king has the function of ordering, bringing fertility, and conveying blessing. He makes laws to establish the right order to prevent chaos and has to connect to the warrior energy to protect the realm if necessary. The function of fertility is linked with creating order and vitality. Blessing by the king is to reinforce a man's self-esteem and his need for recognition. This mature masculine energy "possesses the qualities of order, of reasonable and rational patterning, of integration and integrity in the masculine psyche” (Moore and Gilette 62). In the play’s world 
the only positive father figure is Friar Lawrence, but he is far from embodying the king. Although he sympathizes with Romeo and advises him to act like an adult, he cannot help him order his inner chaos, nor can he offer a mature way of sorting things out.

Although Romeo wants to move in the direction of the king energies, he is caught in a trap. So the question of choice or free will peculiar to a tragic hero becomes in his case an enigma. Does he really have a choice? Does he really choose his love objects as some people think? Does he have a suicidal tendency? Or does the sense of being trapped by the values of Verona make him rash and embrace death rather than a masculinity that goes against his own gentle nature?

Romeo’s impasse justifies Moore and Gilette’s definition of patriarchy as “puerarchy” (143) and shifts attention to the culture as a major force that shapes an individual's destiny. Kiernan Ryan sees Romeo's experience from a Marxist point of view, relates the tragedy of the lovers to the culture, and claims that "Shakespeare shows their plight [that of Romeo and Juliet] to be man-made and mutable" (86). This point has some truth. Romeo and Mercutio are also caught in a certain discourse, and they are too young to transform it. Hillman points to a crucial fact of human existence: "We carry a pack of history on our backs and we are expected to meet the requirements of an old culture. Thus we start out as puer senilis, both older than our age and struggling heroically against our oldness” (37). So individuation is hard because it requires a relentless struggle with the forces that fix us into a definite shape, and both Romeo and Mercutio face the difficulty in a strictly conservative culture.

Romeo and Juliet exposes the tragedy of a patriarchal society, not just of single individuals. We end up agonized by the loss of young people and feel sorry even for the older generation even though they are responsible for the tragedy. Both Mercutio and Romeo are ruined by the kind of manhood imposed on them. Neither of them can succeed in building a strong masculine structure and becoming a truly mature man. Romeo, who embraces the feminine without being threatened, but is somewhat blinded by it, has the masculine courage to defy and "shake the yoke of inauspicious stars" (5.3.111) only when it is of no avail. Mercutio experiences the feminine in a contradictory way and keeps away from it to feel manly. His shadow problem turns him into a tragic figure who claims autonomy in the most reckless and unconstructive way: "I will not budge for no man's pleasure, I” (3.1.54). His potential for bisexual androgyny is, therefore, tragically wasted, but Mercutio at least serves as the medium for us to reflect upon it. The fathers finally shake hands, and the Prince announces: “All are punish'd” (5.3.294). Indeed they are. These supposedly virile men who have not in fact grown beyond their own mothers and fathers are punished by the stars: they are castrated and emasculated by the loss of viable heirs, and neither the sun nor the son of true masculine maturity will ever shine on them.

\section{Notes}

1. Daryl Sharp defines Jung's concept of the shadow as the "repressed desires and uncivilized impulses, morally inferior motives, childish fantasies and resentments, etc. - all those things about oneself one is not proud of” (123)

2. The ambivalence toward the feminine within the Christian tradition that Shakespeare received and the hostility toward the feminine that a number of his women characters complain of, as befits an age when heroic masculinity was still valorized without irony, cast a shadow over masculine individuation in a number of Shakespeare’s plays.

3. All quotations from the play will be from the following edition: Brian Gibbons, ed. The Arden Edition of the Works of William Shakespeare: Romeo and Juliet.

4. On the significance of the feline naming of Tybalt see D. W. Foster, "The Webbing of Romeo and Julie. Foster points to the use of word "Catso" in Q1, which in Italian is associated with the penis, though, it disappears in Q2, and he says that “Tybalt was a traditional name for a cat” (143). 


\section{Works Cited}

Adelman, Janet. “Male Bonding in Shakespeare’s Comedies.” Shakespeare's “Rough Magic”: Renaissance Essays in Honor of C. L. Barber. Ed. Peter Erickson and Coppélia Kahn. London: Associated UP, 1985. 73-103. Print.

Bloom, Allan. Shakespeare on Love and Friendship. London: The U of Chicago P, 1993. Print.

Brooke, Nicholas. Shakespeare's Early Tragedies. London: Methuen, 1968. Print.

Browne, Thomas. “Mercutio as Mercury: Trickster and Shadow.” Upstart Crow 9 (1984): 40-52. Print.

Callaghan, Dympna. C. “The Ideology of Romantic Love.” White 85-115.

Farrell, Kirby. "Love Death, Patriarchy in Romeo and Juliet.” Shakespeare’s Personality. Ed. Holland N. Norman, Sidney Homan, and Bernard J. Paris. Berkeley: U of California P, 1989. 86-102. Print.

Foster, Donald. W. “The Webbing of Romeo and Juliet.” Critical Essays on Romeo and Juliet. Ed. Joseph A. Porter. New York: G. K. Hall, 1997. 131-49. Print.

Garber, Marjorie. B. Coming of Age in Shakespeare. London: Routledge, 1997. Print.

_. Dream in Shakespeare: From Metaphor to Metamorphosis. New Haven: Yale UP, 1974. Print.

Gibbons, Brian, ed. The Arden Edition of the Works of William Shakespeare: Romeo and Juliet. London: Routledge, 1988. Print.

- Introduction. Gibbons. 1-77.

Goldberg, Jonathan. “Romeo and Juliet’s Open Arse.” White 194-212.

Henderson, Joseph. L. Thresholds of Initiation. Middletown: Wesleyan UP, 1967. Print.

Hillman, James. Senex \& Puer. Ed. Glen Slater. Putnam: Spring, 2005. Print.

Holland, Norman. N. “Mercutio, Mine Own Son The Dentist.” Essays on Shakespeare. Ed. G. R. Smith. University Park: Pennsylvania State UP, 1965. 3-14. Print.

Hyde, Lewis. Trickster Makes This World. New York: North Point, 1999. Print.

Jung, Carl. G. Aion: Researches into the Phenomenology of the Self. 1978. The Collected Work of C. G. Jung. Ed. Sir Herbert Read et al. Trans. R. F. C. Hull. 2nd ed. Vol 9. Princeton: Princeton UP, 1953-79. Print. 20 vols. Bollingen Ser. 20.

Aspects of the Masculine. Ed. John Beebe. London: Routledge, 1989. Print.

Kahn, Coppélia. “Coming of Age in Verona.” Modern Language Studies 8.1 (1977-78): 5-22. Print.

Leech, Clifford. “The Moral Tragedy of Romeo and Juliet.” Porter, Critical Essays on Romeo and Juliet. 7-22.

Monick, Eugene. Phallos: The Sacred Image of the Masculine. Toronto: Inner City, 1987. Print.

Moore, Robert, and Douglas Gilette. King Warrior Magician Lover: Rediscovering the Archetypes of the Mature Masculine. New York: Harper Collins, 1991. Print.

Occhiogrosso, Frank. “Mercutio’s Broken Syntax.” Shakespeare Newsletter 59 (2009): 5-12.

Porter, Joseph A. ed. Shakespeare's Mercutio: His History and Drama. Chapel Hill: The U of North Caroline P, 1988. Print.

Ryan, Kiernen. Shakespeare. 2nd ed. Hertfordshire: Prentice Hall, 1995. Print.

Sharp, Daryl. Jung Lexicon: A Primer of Terms and Concepts. Toronto: Inner City, 1991. Print.

Sinfield, Alan. Shakespeare, Authority, Sexuality: Unfinished Business in Cultural Materialism. London: Routledge, 2006. Print.

White, R. S., ed. Romeo and Juliet: Contemporary Critical Essays: New Casebooks. New York: Palgrave, 2001. Print. 